\title{
The Impact of CB2 Receptor Ligands on the MK-801-Induced Hyperactivity in Mice
}

\author{
Marta Kruk-Slomka $^{1}$ - Izabela Banaszkiewicz ${ }^{1} \cdot$ Grazyna Biala $^{1}$
}

Received: 20 September 2016 /Revised: 5 January 2017 / Accepted: 11 January 2017 / Published online: 30 January 2017

(C) The Author(s) 2017. This article is published with open access at Springerlink.com

\begin{abstract}
It has been known that there is a relationship between cannabis use and schizophrenia-related symptoms; however, it can be a subject of controversy. The involvement of $\mathrm{CB} 1$ receptor ligands in the schizophrenia has already been revealed and confirmed. However, there is still lack of information concerning the role of $\mathrm{CB} 2$ receptors in the psychosislike effects in mice and the further studies are needed.

The aim of the present research was to study the role of the CB2 receptor ligands in the symptoms typical for schizophrenia. We provoked hyperlocomotion in mice which is analogous to positive psychosis-like effects in humans, by an acute administration of a NMDA receptor antagonist, MK-801 ( 0.3 and $0.6 \mathrm{mg} / \mathrm{kg}$ ), a pharmacological model of schizophrenia. An acute administration of MK-801 induced the increase in locomotor activity (hyperactivity) in rodents, measured in actimeters.

We revealed that an acute injection of $\mathrm{CB} 2$ receptor agonist JWH 133 at the dose range $(0.05-1.0 \mathrm{mg} / \mathrm{kg})$ and CB2 receptor antagonist, AM 630 at the dose range $(0.1-1.0 \mathrm{mg} / \mathrm{kg})$ decreased locomotion of mice. An acute injection of JWH $133(2.0 \mathrm{mg} / \mathrm{kg})$ and AM $630(2.0 \mathrm{mg} / \mathrm{kg})$ had no statistical significant influence on the locomotor activity of mice. However, an acute injection of both CB2 receptor ligands (agonist and antagonist), JWH 133, at the non-effective dose of $2.0 \mathrm{mg} / \mathrm{kg}$ and AM 630 at the non-effective dose of $2.0 \mathrm{mg} / \mathrm{kg}$, potentiated the MK-801-induced hyperactivity.
\end{abstract}

Marta Kruk-Slomka

marta.kruk@umlub.pl

1 Department of Pharmacology and Pharmacodynamics, Medical University of Lublin, Chodzki 4a Street, 20-093 Lublin, Poland
The present findings have confirmed that endocannabinoid system, not only via $\mathrm{CB} 1$, but also via $\mathrm{CB} 2$ receptors, may be involved in the schizophrenia-like responses, including hyperlocomotion in mice.

Keywords Schizophrenia $\cdot$ Cannabis use $\cdot$ Endocannabinoid system $\cdot$ CB2 receptor ligands $\cdot$ MK- $801 \cdot$ Mice

$\begin{array}{ll}\text { Abbreviations } & \\ \Delta 9-\text { THC- } \Delta 9 & \text { Tetrahydrocannabinol } \\ \text { CB1 } & \text { Cannabinoid receptor of type 1 } \\ \text { CB2 } & \text { Cannabinoid receptor of type 2 } \\ (\mathrm{CB} 1-/-) & \text { CB1 receptor knockout mice } \\ (\mathrm{CB} 2-/-) & \text { CB2 receptor knockout mice } \\ \text { CB } & \text { Cannabinoid } \\ \text { CBD } & \text { Cannabidiol } \\ \text { CNS } & \text { Central nervous system } \\ \text { GABA } & \text { 7-Amino-butyric acid } \\ \text { ip } & \text { Intraperitoneally } \\ \text { mRNA } & \text { Messenger ribonucleic acid } \\ \text { NMDA } & N \text {-methyl-D-aspartate } \\ \text { PPI } & \text { Prepulse inhibition } \\ \text { WT } & \text { Wild type } \\ \text { VTA } & \text { Ventral tegmental area }\end{array}$

\section{Introduction}

Schizophrenia is a chronic mental disorder that combines a variety of clinical symptoms, including positive (e.g., hallucinations, psychosis), negative (e.g., amotivation, anhedonia), and cognitive (e.g., deficits in attention and memory) symptoms (Lewis and Lieberman, 2000). As yet, the etiology of schizophrenia remains unclear. 
Experts support that schizophrenia is caused by several factors, including gene- and environment-related factors, as well as by an imbalance in the function of many neurotransmitters systems, e.g., dopaminergic, glutamatergic, gamma-aminobutyric(GABA)-related system, endocannabinoid system, and possibly others (Broome et al. 2005; Carlsson et al. 2004).

The endocannabinoid system, through cannabinoid (CB) receptors, and its interactions with a multitude of neurotransmitters and receptors, is involved in many physiological and physical functions, which correspond with distribution of CB receptors (Grotenhermen 2004). Currently, two types of $\mathrm{CB}$ receptors are known: $\mathrm{CB} 1$ and $\mathrm{CB} 2$. $\mathrm{CB} 1$ receptors are widely distributed in the central nervous system (CNS), especially in the limbic system and on the brain areas related to emotional responses, including basal ganglia, amygdala, cerebellum, hippocampus, and prefrontal cortex. In turn, CB2 receptors are mostly located in cells of the immune system and can be also found on the brain areas, such as cerebellum and hippocampus and in microglia (Svízenská et al. 2008). Due to localization of $\mathrm{CB}$ ( $\mathrm{CB} 1$ as well $\mathrm{CB} 2$ ) receptors, endocannabinoid system is able to modulate many cognitive- and emotional-related responses in the CNS, e.g., stress, anxiety, mood, and aggressive behavior. Thus, this system plays an important role in the pathology of many CNS-related disorders, such as depression, memory loss, and schizophrenia (Grotenhermen 2004).

Recently, many literature data support that changes in the endocannabinoid system in the brain may be involved in the pathology of schizophrenia, and this system is impaired in schizophrenia. Furthermore, there is emerging evidence to support a number of associations between cannabis and psychosis. Several lines of experimental and clinical evidence point to a close relationship between endocannabinoid system and schizophrenia as cannabis use may precipitate or exacerbate the symptoms of this disease. Some studies have indicated that exposure to cannabis is associated with cognitive impairment and increased risk of developing psychosis (Arseneault et al. 2004; Moore et al. 2007). Additionally, there is evidence that the brains of people with psychosis who previously used cannabis differ significantly from those of healthy individuals (Rapp et al. 2012). Moreover, it has been revealed that people with psychosis have higher rates of cannabis use, and that there exists an association between cannabis use and schizophrenia, and other research has consistently found that cannabis use is associated with an earlier age at onset of schizophrenia (Large et al. 2011).

This relationship has been confirmed in behavioral experiments (Liu et al. 2009; Marsicano et al. 2003). A variety of animal studies found a dysregulation of endocannabinoid signaling in psychosis. For example, in animal models, it has been demonstrated that CB1 receptor agonists often induced cognitive impairments in rodents (Ferrari et al. 1999; Kruk-Slomka and Biala 2016; Pamplona and Takahashi 2006) and induced psychosis-like symptoms (Levin et al. 2012; Roser and Haussleiter, 2012). However, it is still not clear whether and why the use of cannabis causes or exacerbates psychosis.

On the other hand, due to their properties, cannabinoids appear to be a promising therapeutic target in the treatment of many diseases, such as psychosis-like symptoms. It has been revealed that antagonism of CB1 receptors generally enhanced rodent performance in variety memory tasks (Kruk-Slomka and Biala 2016; Kruk-Slomka et al. 2016a; Kruk-Slomka et al. 2016b; Lichtman 2000; Takahashi et al. 2005; Terranova et al. 1996), as well as had antipsychotic properties evaluated in animal models of schizophrenia (Almeida et al. 2014; Kruk-Slomka et al. 2016b; Levin et al. 2012; Roser and Haussleiter 2012; Radhakrishnan et al. 2014).

Since then, a number of studies have investigated the association between cannabis and psychosis. Although, the involvement of CB1 receptor ligands in the schizophrenia has already been revealed and confirmed (KrukSlomka et al. 2016b), there is still lack of clear evidence regarding the central mechanisms of action and effects of $\mathrm{CB} 2$ receptor ligands, especially the role of $\mathrm{CB} 2$ receptors in the processes connected with the psychosis-like symptoms. There is only a few literature data indicating a possible role of $\mathrm{CB} 2$ receptors in schizophrenia-related responses (Ishiguro et al. 2010; Khella et al. 2014; Ortega-Alvaro et al. 2011). Therefore, continuing in the line of our earlier studies (Kruk-Slomka et al. 2016b), in which we revealed and confirmed that $\mathrm{CB} 1$ receptor antagonist is able to attenuate the MK-801-induced hyperlocomotion, the aim of presented studies was to determine the potential antipsychotic status of $\mathrm{CB} 2$ receptor ligands and their influence on the hyperactivity in mice in this pharmacological model. We used CB2 receptor agonist, JWH 133 and CB2 receptor antagonist, AM 630. Alike the previous experiments (Kruk-Slomka et al. 2016b), we induced an increased locomotion in mice by an acute administration of $N$-methyl-D-aspartate (NMDA) receptor antagonist, $\mathrm{MK}-801$, which is often used to predict the effect of many compounds with potential antipsychotic properties (Kovacic and Somanathan 2010).

The results obtained from these experiments will help to confirm the role for $\mathrm{CB} 2$ receptor subtype in the modulation of behaviors associated with an animal model of hyperlocomotion and schizophrenia. Following that, our results can also help to increase knowledge concerning the relationship between cannabis use and psychosis, focusing on the $\mathrm{CB} 2$ receptors, and to explain precise nature of these associations more clearly. 


\section{Materials and Methods}

\section{Animals}

Male Swiss mice (Farm of Laboratory Animals, Warszawa, Poland) weighting 20-30 g were housed under laboratory conditions of controlled temperature $\left(21 \pm 1{ }^{\circ} \mathrm{C}\right)$, lighting (12/12 h light/dark cycle) with food (Agropol, Motycz, Poland) and tap water available ad libitum. Animals were habituated to housing conditions for 1 week and behavioral testing was carried out during the light cycle (between 8:00 and 15:00).

Mice were used only once and were drug-naive before each experiment. Experiments were performed in accordance with the National Institute of Health Guidelines for the Care and Use of Laboratory Animals and the European Community Council Directive for the Care and Use of laboratory animals of 22 September $2010(2010 / 63 / \mathrm{EU})$, and approved by the local ethics committee.

\section{Drugs}

The following drugs were used:

1. JWH $133(0.05,0.1,0.25,0.5,1.0,2.0 \mathrm{mg} / \mathrm{kg}$ ) (Tocris, USA)—CB2 receptor agonist

2. AM $630(0.1,0.25,0.5,1.0,2.0 \mathrm{mg} / \mathrm{kg})$ (Tocris, USA)$C B 2$ receptor antagonist

3. MK-801 (0.3, $0.6 \mathrm{mg} / \mathrm{kg})$ (Tocris, USA)—NMDA receptor antagonist

CB2 receptor ligands and MK-801 were suspended in the $1 \%$ solution of polyoxyethylenesorbitan monooleate (Tween 80) (Sigma, St. Louis, MO, USA) and then diluted in a $0.9 \%$ saline solution $(\mathrm{NaCl})$. All solutions were injected intraperitoneally (ip) at a volume of $10 \mathrm{ml} / \mathrm{kg}$ body weight. Saline plus Tween 80 was used as a control solution (vehicle), at the same volume and by the same route of administration. Fresh drug solutions were prepared on each day of experimentation.

Experimental doses of drugs used and procedures were selected on the basis of literature data (Bubenikova-Valesova et al. 2010; Kovacic and Somanathan 2010; Nestler and Hyman 2010; Mohn et al. 1999; Zhou et al. 2012), our previous experiments (Kruk-Slomka et al. 2015; Kruk-Slomka and Biala 2016; Kruk-Slomka et al. 2016a; Kruk-Slomka et al. 2016b), and preliminary studies. The doses of MK-801 as well as the scheme of treatment was based on our previous experiments (Kruk-Slomka et al. 2016b).

\section{Experimental Procedures}

Schizophrenia-like behavior was assessed using the commonly accepted pharmacological animal model of schizophrenia based on psychotic properties of MK-801. Mice were acutely injected with MK-801 inducing hyperlocomotion which correlates with the psychomotor agitation seen in schizophrenia patients (Bubenikova-Valesova et al. 2010; Nestler and Hyman 2010).

Firstly, the influence of CB2 receptor ligands, JWH 133 and AM 630, on the locomotor activity of mice was investigated and then the impact of JWH 133 and AM 630 on the hyperactivity provoked by MK- 801 was estimated. Locomotion of mice was measured in actimeters.

\section{Locomotion}

Locomotion of mice was recorded individually in round actometer cages (Multiserv, Lublin, Poland; $32 \mathrm{~cm}$ in diameter, two light beams) kept in a sound-attenuated experimental room. Two photocell beams, located across the axis, automatically measured animal's movements. The horizontal locomotor activity, i.e., the number of photocell beam breaks, was automatically measured with a 20 -min interval for $200 \mathrm{~min}$ (Mohn et al. 1999; Zhou et al. 2012).

\section{Treatment}

\section{For Psychotic-like Symptoms}

Horizontal locomotor activity was measured immediately after an acute injection of JWH $133(0.05,0.1,0.25,0.5,1.0$, $2.0 \mathrm{mg} / \mathrm{kg}$, ip), AM 630 (0.1, 0.25, 0.5, 1.0, $2.0 \mathrm{mg} / \mathrm{kg}$, ip), or vehicle for the control group. Next, we evaluated the impact of an acute administration of JWH $133(2.0 \mathrm{mg} / \mathrm{kg}$, ip) or AM $630(2.0 \mathrm{mg} / \mathrm{kg}$, ip) on the hyperlocomotion of mice provoked by an acute MK- 801 ( 0.3 and $0.6 \mathrm{mg} / \mathrm{kg}$, ip). For this purpose, JWH 133, AM 630, or vehicle were administered $15 \mathrm{~min}$ before injection of MK- 801 or vehicle. The mice were then tested immediately after the last injection.

\section{Statistical Analysis}

The statistical analysis were performed using two-way ANOVA - for the factors of time, drug treatment (JWH 133, AM 630, and/or MK-801), and time/drug treatment interactions for the locomotor effects.

Post hoc comparison of means was carried out with the Bonferroni's test for multiple comparisons, when appropriate. The data were considered statistically significant at confidence limit of $p<0.05$. ANOVA analysis with Bonferroni's post tests were performed using GraphPad Prism version 5.00 for Windows, GraphPad Software, San Diego California USA, www.graphpad.com.

For the psychotic-like symptoms, the horizontal locomotor activity, i.e., the number of photocell beam breaks, was measured. 


\section{Results}

First, we evaluated the influence of CB2 receptor ligands (agonist and antagonist) on the locomotion of mice in actimeters. An acute injection of JWH 133, CB2 receptor agonist decreased locomotion of mice at the dose range $0.05-1.0 \mathrm{mg} / \mathrm{kg}$. Similarly, an acute injection of AM 630. CB2 receptor antagonist, decreased locomotion of mice at the dose range 0.1$1.0 \mathrm{mg} / \mathrm{kg}$. In turn, an acute injection of both JWH 133 at the dose of 2.0 and AM 630 at the dose of 2.0 had no influence on the locomotion of mice. Therefore, these non-effective doses of JWH 133 and AM $630(2.0 \mathrm{mg} / \mathrm{kg})$ have been chosen to the next experiments dealing MK-801.

\section{The Influence of CB2 Receptor Agonist, JWH 133, on the Locomotor Activity of Mice}

Two-way ANOVA analyses revealed that there was statistically significant effect caused by time $[F(10,418)=44.04$, $p<0.0001]$ and JWH 133 treatment $[F(6418)=16.30$, $p<0.0001]$, but there was no statistically significant effect caused by interactions between time and JWH 133 treatment $[F(60,418)=0.94, p=0.6122]$. The Bonferroni's test revealed that an acute injection of JWH 133, at the dose range (0.05$1.0 \mathrm{mg} / \mathrm{kg}$ ), significantly decreased locomotion in mice in comparison to the vehicle-treated control group between the following minutes of the experiment as follows:

1. Between 140 and $200 \mathrm{~min}$ of experiment for the dose of $0.05 \mathrm{mg} / \mathrm{kg}$ of JWH 133: $140 \mathrm{~min}(p<0.05), 160 \mathrm{~min}$ $(p<0.01)$, and $180-200 \min (p<0.001)$

2. Between 100 and $200 \mathrm{~min}$ of experiment for the dose of $0.1 \mathrm{mg} / \mathrm{kg}$ of JWH 133: $100 \mathrm{~min}(p<0.05), 120 \mathrm{~min}$ $(p<0.01)$, and 140-200 $\min (p<0.001)$

3. Between 180 and $200 \mathrm{~min}$ of experiment for the dose of $0.25 \mathrm{mg} / \mathrm{kg}$ of JWH 133: $p<0.01$

4. Between 180 and $200 \mathrm{~min}$ of experiment for the dose of $0.5 \mathrm{mg} / \mathrm{kg}$ of JWH 133: $180 \mathrm{~min}(p<0.05), 200 \mathrm{~min}$ $(p<0.01)$

5. Between 120 and $200 \mathrm{~min}$ of experiment for the dose of $1.0 \mathrm{mg} / \mathrm{kg}$ of JWH 133: $120 \mathrm{~min}(p<0.05), 140-180 \mathrm{~min}$ $(p<0.01), 200 \min (p<0.001)$

JWH 133 at the dose of $2.0 \mathrm{mg} / \mathrm{kg}$ had no influence on the locomotor activity of mice in comparison to the vehicletreated control group (Fig. 1).

\section{The Influence of CB2 Receptor Antagonist, AM 630 on the Locomotor Activity of Mice}

Two-way ANOVA analyses revealed that there was statistically significant effect caused by time $[F(10,341)=40.07$, $p<0.0001]$ and AM 630 treatment $[F(5341)=20.01$, $p<0.0001]$, but there was no statistically significant effect caused by interactions between time and AM 630 treatment $[F(50,341)=1.20, p=0.1827]$. The Bonferroni's test revealed that an acute injection of AM 630 at the dose range (0.1$1.0 \mathrm{mg} / \mathrm{kg}$ ) significantly decreased locomotion in mice in comparison to the vehicle-treated control group between the following minutes of the experiment as follows:

1. Between 140 and $200 \mathrm{~min}$ of experiment for the dose of $0.1 \mathrm{mg} / \mathrm{kg}$ of AM 630: $140-160 \mathrm{~min}(p<0.05), 180 \mathrm{~min}$ $(p<0.01)$, and $200 \min (p<0.001)$

2. Between 100 and $200 \mathrm{~min}$ of experiment for the dose of $0.25 \mathrm{mg} / \mathrm{kg}$ of AM 630: $100 \mathrm{~min}(p<0.05), 120 \mathrm{~min}$ $(p<0.01)$, and $140-200 \min (p<0.001)$

3. Between 120 and $200 \mathrm{~min}$ of experiment for the dose of $0.5 \mathrm{mg} / \mathrm{kg}$ of AM 630: $120 \mathrm{~min}(p<0.05), 140 \mathrm{~min}$ $(p<0.01)$, and $160-200 \mathrm{~min}(p<0.001)$

4. Between 160 and $200 \mathrm{~min}$ of experiment for the dose of $1.0 \mathrm{mg} / \mathrm{kg}$ of AM 630: $160 \mathrm{~min}(p<0.05)$ and 180 $200 \min (p<0.01)$

AM 630 at the dose of $2.0 \mathrm{mg} / \mathrm{kg}$ had no influence on the locomotor activity of mice in comparison to the vehicletreated control group (Fig. 2).

Then, we induced the hyperlocomotion which mimics positive symptom characteristic for schizophrenia, by an acute administration of MK-801, and evaluated the influence of CB2 receptor ligands on this MK-801-related hyperactivity. Based on our previously conducted experiments (KrukSlomka et al. 2016b) as well as on the results obtained from the experiments described above, the effective doses of MK$801(0.3$ and $0.6 \mathrm{mg} / \mathrm{kg})$ and non-effective dose of JWH 133 $(2.0 \mathrm{mg} / \mathrm{kg})$ and AM $630(2.0 \mathrm{mg} / \mathrm{kg})$ were then chosen for the next behavioral experiment evaluating the involvement of CB2 receptors on MK-801-induced hyperactivity.

In these experiments, we revealed that an acute injection of both $\mathrm{CB} 2$ receptor agonist and antagonist had influence on the MK-801-induced hyperlocomotion of mice. The noneffective dose of JWH $133(2.0 \mathrm{mg} / \mathrm{kg})$ potentiated the hyperlocomotion of mice provoked by an acute injection of MK-801 at the dose of $0.6 \mathrm{mg} / \mathrm{kg}$. Similarly, an acute injection of non-effective dose of AM $630(2.0 \mathrm{mg} / \mathrm{kg})$ potentiated the hyperlocomotion of mice provoked by an acute injection of MK- 801 both at the dose of 0.3 and $0.6 \mathrm{mg} / \mathrm{kg}$, as described below.

\section{The Influence of the Administration of JWH 133 on the Hyperactivity of Mice Provoked by an Acute Administration of MK-801}

Two-way ANOVA analyses revealed that there was statistically significant effect caused by time $[F(10,264)=32.84$, $p<0.0001]$ and drug (MK-801 (0.3 mg/kg) and/or JWH 133 
Fig. 1 Effects of an acute JWH 133 or vehicle administration on the locomotor activity of mice. JWH 133 (0.05, 0.1, 0.25, 0.5, 1.0 , and $2.0 \mathrm{mg} / \mathrm{kg}$; ip) or vehicle were injected immediately before the test; $n=8-12$; the means $\pm \mathrm{SEM} ; * p<0.05$; $* * p<0.01 ; * * * p<0.001$ vs. vehicle-treated control group; Bonferroni's test

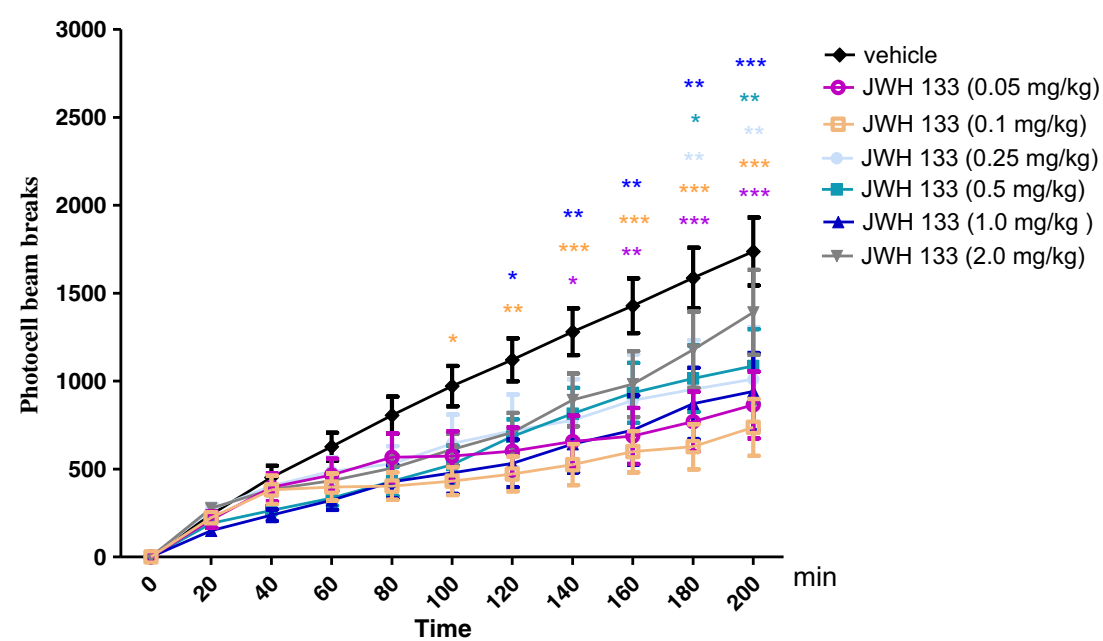

$(2.0 \mathrm{mg} / \mathrm{kg})$ treatment $[F(3264)=81.27, p<0.0001]$, as well as caused by interactions between time and drug treatment $[F(30,264)=2.73, p<0.0001]$. The post hoc Bonferroni's test confirmed that an acute injection of MK-801 at the dose of $0.3 \mathrm{mg} / \mathrm{kg}$ significantly increased locomotor activity of mice between 60 and $200 \mathrm{~min}$ of experiment as compared with the vehicle/vehicle-injected control group (for 60-80 $\mathrm{min}$ of experiments $p<0.05$, for $100-120 \mathrm{~min} p<0.01$, for $140 \mathrm{~min}$ $p<0.001$, for $160 \mathrm{~min} p<0.01$, and for $180-200 \mathrm{~min}$ $p<0.001)$. JWH $133(2.0 \mathrm{mg} / \mathrm{kg})$ had no influence on MK$801(0.3 \mathrm{mg} / \mathrm{kg})$-induced hyperactivity (Fig. 3a).

For the second dose of MK- 801 used $(0.6 \mathrm{mg} / \mathrm{kg})$, two-way ANOVA analyses revealed that there was statistically significant effect caused by time $[F(10,264)=80.87, p<0.0001]$, and drug (MK-801 (0.6 mg/kg) and/or JWH $133(2.0 \mathrm{mg} / \mathrm{kg})$ treatment $[F(3264)=213.39, p<0.0001]$, as well as by interactions between time and drug treatment $[F(30,264)=8.72$, $p<0.0001]$. The post hoc Bonferroni's test revealed that MK801 at the dose of $0.6 \mathrm{mg} / \mathrm{kg}$ significantly increased locomotor activity of mice in actimeters between 60 and $200 \mathrm{~min}$ of experiment (for $60 \mathrm{~min}$ of experiment $p<0.01$, for 80 $200 \min p<0.001$ ), in comparison to the vehicle/vehicletreated mice. Moreover, this hyperactivity provoked by MK$801(0.6 \mathrm{mg} / \mathrm{kg})$ was potentiated by JWH $133(2.0 \mathrm{mg} / \mathrm{kg})$ between 180 and $200 \mathrm{~min}$ of experiment ( $p<0.05 \mathrm{vs}$. vehicle/MK-801 (0.6 mg/kg)-treated mice) (Fig. 3b).

\section{The Influence of the Administration of AM 630 on the Hyperactivity of Mice Provoked by an Acute Administration of MK-801}

Two-way ANOVA analyses revealed that there was statistically significant effect caused by time $[F(10,242)=66.29$, $p<0.0001]$ and drug (MK-801 $(0.3 \mathrm{mg} / \mathrm{kg})$ and/or AM 630 $(2.0 \mathrm{mg} / \mathrm{kg})$ treatment $[F(3242)=261.74, p<0.0001]$, as well as caused by interactions between time and drug treatment $[F(30,242)=8.11, p<0.0001]$. The post hoc Bonferroni's test confirmed that an acute injection of MK801 at the dose of $0.3 \mathrm{mg} / \mathrm{kg}$ significantly increased locomotor activity of mice between 40 and $200 \mathrm{~min}$ of
Fig. 2 Effects of an acute AM 630 or vehicle administration on the locomotor activity of mice. AM $630(0.1,0.25,0.5,1.0$, and $2.0 \mathrm{mg} / \mathrm{kg}$; ip) or vehicle were injected immediately before the test; $n=8-12$; the means \pm SEM; $* p<0.05 ; * * p<0.01$;

$* * * p<0.001$ vs. vehicle-treated control group; Bonferroni's test

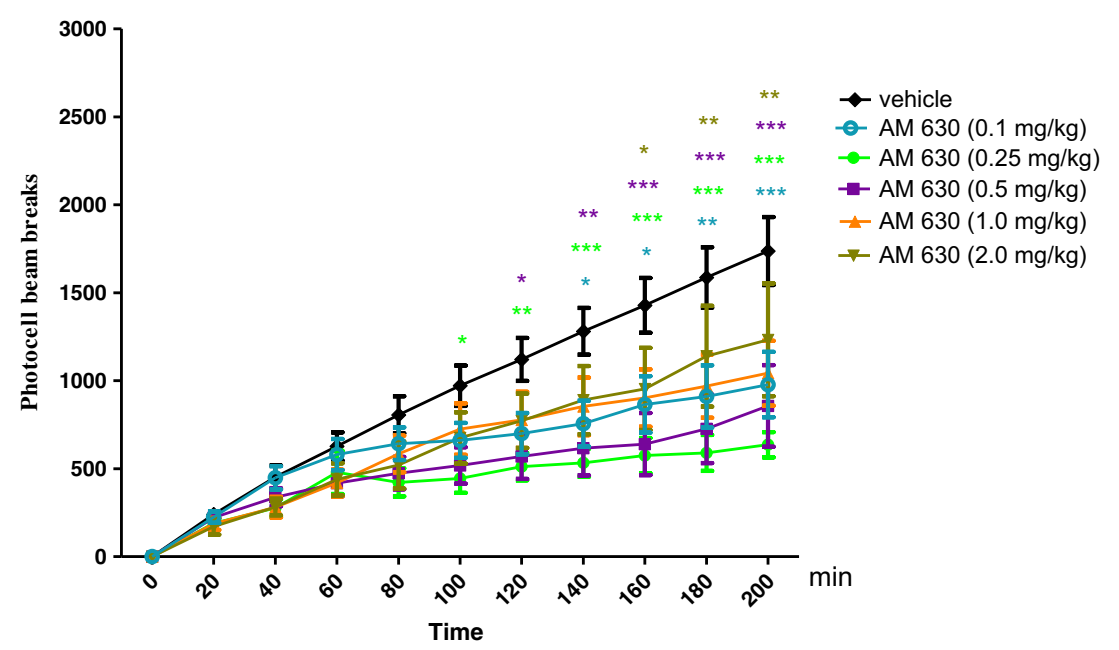


Fig. 3 Effect of JWH 133 on MK-801-induced hyperactivity in mice. Non-effective dose of JWH $133(2.0 \mathrm{mg} / \mathrm{kg}$, ip) or vehicle were administered $15 \mathrm{~min}$ prior to vehicle or effective $(0.3 \mathrm{mg} / \mathrm{kg}$, ip) (a) and $(0.6 \mathrm{mg} / \mathrm{kg}$, ip) (b) dose of MK-801. After the last injection, the mice were then tested in actimeters; $n=8-12$; the means \pm SEM; $* p<0.05$; $* * p<0.01 ; * * * p<0.001 \mathrm{vs}$. vehicle/vehicle-treated group; ${ }^{\wedge} p<0.05$ vs. vehicle/MK$801(0.6 \mathrm{mg} / \mathrm{kg})$-treated group Bonferroni's test

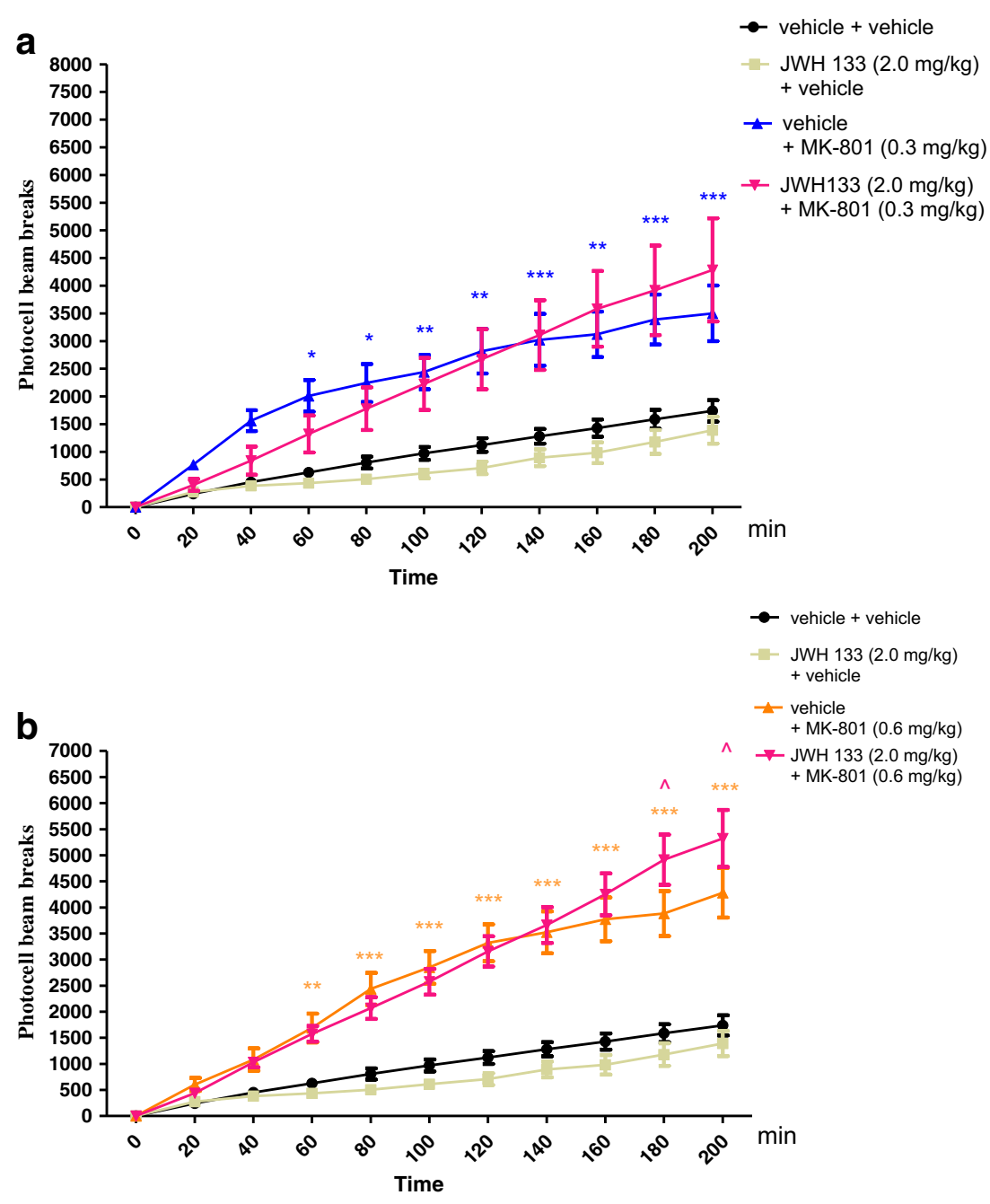

experiment as compared with the vehicle/vehicle-injected control group (for $40 \mathrm{~min}$ of experiment $p<0.01$, for 60 $200 \min p<0.001)$. Moreover, this hyperactivity provoked by MK-801 $(0.3 \mathrm{mg} / \mathrm{kg})$ was potentiated by an acute injection of AM $630(2.0 \mathrm{mg} / \mathrm{kg})$ between 100 and $200 \mathrm{~min}$ of experiment (for $100 \mathrm{~min}$ of experiment $p<0.05$, for 120 $200 \mathrm{~min}$ of experiment $p<0.001$ vs. vehicle/MK-801 (0.3 mg/kg)-treated mice) (Fig. 4a).

Similarly, for the second dose of MK-801 used $(0.6 \mathrm{mg} / \mathrm{kg})$, two-way ANOVA analyses revealed that there was statistically significant effect caused by time $[F(10,242)=67.19$, $p<0.0001]$ and drug (MK-801 $(0.6 \mathrm{mg} / \mathrm{kg})$ and/or AM 630 $(2.0 \mathrm{mg} / \mathrm{kg})$ treatment $[F(3242)=213.41, p<0.0001]$, as well as by interactions between time and drug treatment $[F(30,242)=8.58, p<0.0001$. The post hoc Bonferroni's test revealed that MK- 801 at the dose of $0.6 \mathrm{mg} / \mathrm{kg}$ significantly increased locomotor activity of mice in actimeters between 80 and $200 \mathrm{~min}$ of experiment ( $p<0.001$ ), in comparison to the vehicle/vehicle-treated mice. Moreover, this hyperactivity provoked by MK-801 (0.6 mg/kg) was increased by AM
$630(2.0 \mathrm{mg} / \mathrm{kg})$ between 140 and $200 \mathrm{~min}$ of experiment (for $140 \mathrm{~min}$ of experiment $p<0.05$, for $160 \min p<0.01$, for 180-200 min of experiment $p<0.001$ vs. vehicle/MK-801 (0.6 mg/kg)-treated mice) (Fig. 4b).

\section{Discussion}

The aim of the present research was to determine the involvement of the endocannabinoid system, through CB2 receptors, in the hyperlocomotion of mice, provoked by an acute injection of NMDA receptor antagonist, MK-801, as an animal pharmacological model of schizophrenia.

We revealed that an acute injection of AM 630, CB2 receptor antagonist, used in our experiments at the doses $0.1-$ $1.0 \mathrm{mg} / \mathrm{kg}$, but not at the dose of $2.0 \mathrm{mg} / \mathrm{kg}$, decreased locomotion of mice. An acute injection of AM $630(2.0 \mathrm{mg} / \mathrm{kg})$ of its own had no statistical significant influence on the locomotor activity of mice. However, in the next step, we revealed that an acute injection of AM 630, at the non-effective dose of 
Fig. 4 Effect of AM 630 on MK801-induced hyperactivity in mice. Non-effective dose of AM $630(2.0 \mathrm{mg} / \mathrm{kg}$, ip) or vehicle were administered $15 \mathrm{~min}$ prior to vehicle or effective $(0.3 \mathrm{mg} / \mathrm{kg}$, ip) (a) and ( $0.6 \mathrm{mg} / \mathrm{kg}$; ip) (b) dose of MK-801. After the last injection, the mice were then tested in actimeters; $n=8-12$; the means \pm SEM; $* * p<0.01$;

$* * * p<0.001$ vs. vehicle/vehicletreated group; $\& p<0.05$;

$\& \& \& p<0.001$ vs. vehicle/MK$801(0.3 \mathrm{mg} / \mathrm{kg})$-treated group; ${ }^{\wedge} p<0.05 ; \wedge \wedge p 0.01 ;$ $\wedge \wedge p<0.001$ vs. vehicle/MK$801(0.6 \mathrm{mg} / \mathrm{kg})$-treated group; Bonferroni's test

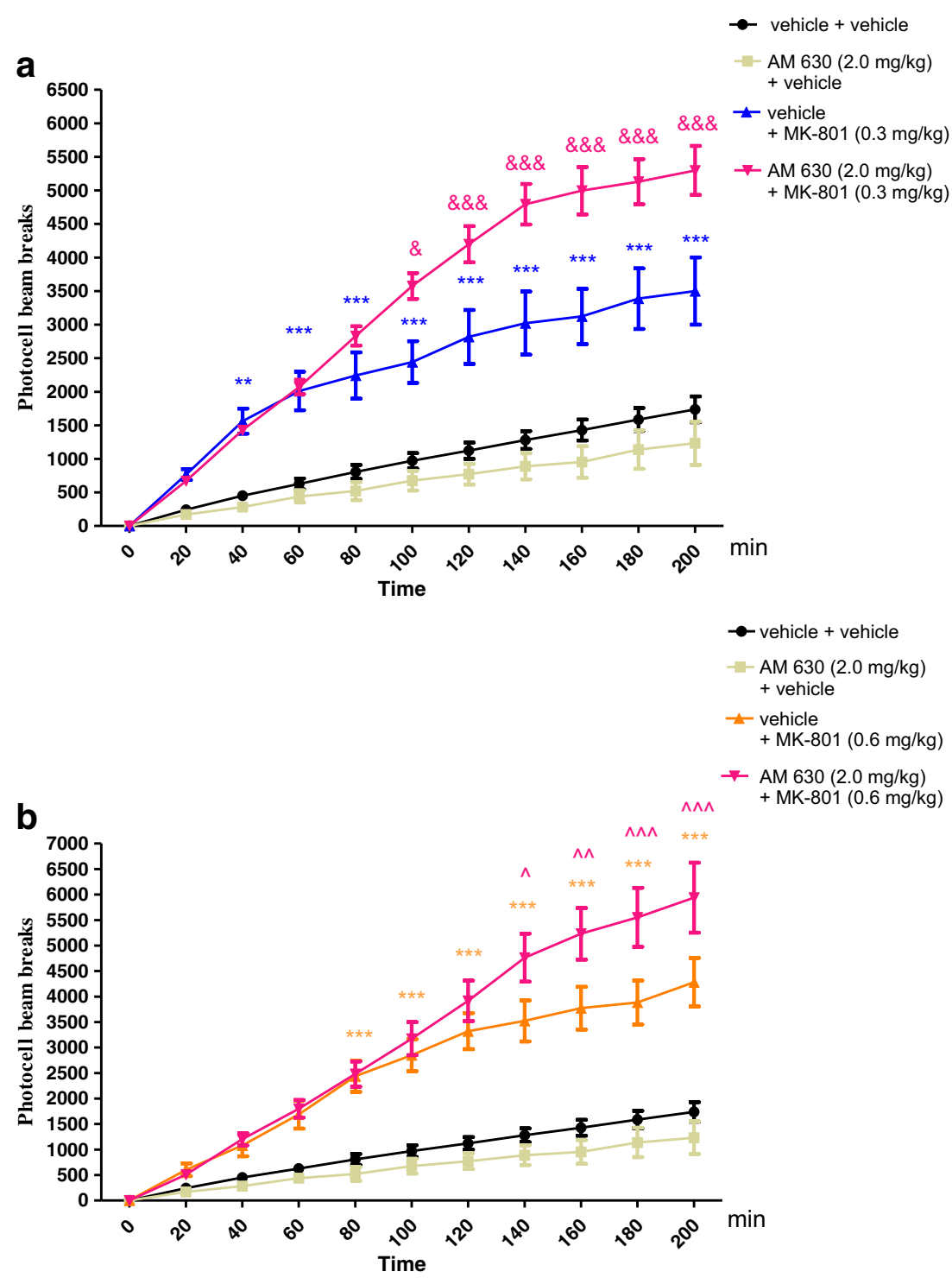

$2.0 \mathrm{mg} / \mathrm{kg}$, potentiated MK-801-induced hyperactivity. What is of interest, we revealed that an acute injection of JWH 133, CB2 receptor agonist, used in our experiments at the doses $0.05-1.0 \mathrm{mg} / \mathrm{kg}$, but not at the dose of $2.0 \mathrm{mg} / \mathrm{kg}$, also decreased locomotion of mice. An acute injection of JWH 133 $(2.0 \mathrm{mg} / \mathrm{kg})$ of its own had no statistical significant influence on the locomotor activity of mice. However, an acute injection of JWH 133 at the non-effective dose of $2.0 \mathrm{mg} / \mathrm{kg}$ intensified the MK-801-provoked hyperactivity.

The first CB2 receptor ligand-related effect that should be discussed is associated with the fact that both the CB2 agonist $(2.0 \mathrm{mg} / \mathrm{kg}$; not a lower dose) and CB2 antagonist $(2.0 \mathrm{mg} / \mathrm{kg}$; not a lower dose) altered MK-801 locomotor effects (similar effects). The second interest CB2 receptor ligand effect should focused on the fact that these cannabinoid compounds had no effect of their own (i.e., without MK-801 injection) on locomotor activity.
The increase of MK-801 induced hyperactivity caused by both CB2 antagonist and CB2 agonist obtained in our studies seems to be very important. The same direction of action we have is revealed in our previous studies. We have shown the enhancement of memory and learning processes by an acute administration of CB2 receptor agonist (JWH 133 at the doses of $0.5 ; 1.0$ and $2.0 \mathrm{mg} / \mathrm{kg}$ ) and antagonist (AM 630 at the dose of $1.0 ; 2.0$ and $3.0 \mathrm{mg} / \mathrm{kg}$ ) assessed in the passive avoidance (PA) test (Kruk-Slomka et al. 2016a). Similarly, we have revealed that an acute administration of both JWH 133 ( 0.5 and $1.0 \mathrm{mg} / \mathrm{kg})$ and AM $630(0.5 \mathrm{mg} / \mathrm{kg})$ exhibited antidepressant action in the forced swimming test (FST) (Kruk-Slomka et al. 2015). These results confirmed in our present and previous cited experiments may be connected with pharmacokinetic properties of used CB2 receptor ligands, especially the CB2selective agent, AM 630. The pharmacological properties of AM 630 are complex. It has been shown that AM 630 behaves 
as inverse agonist rather than as "silent" antagonist. The inverse efficacy at $\mathrm{CB} 2$ receptors but also the $\mathrm{CB} 2 / \mathrm{CB} 1$ affinity ratio has been indicated for $\mathrm{AM} 630(\mathrm{CB} 2 / \mathrm{CB} 1$ affinity $=165)$. Thus, AM 630 has been found to behave as an inverse agonist at $\mathrm{CB} 2$ receptors as well as an inverse agonist at $\mathrm{CB} 1$ receptors (Bolognini et al. 2012; Ross et al. 1999).

Naturally, the administration of different doses of selective CB2 receptor agonists/antagonists provides some information for a neurophysiological role of CB2 receptors in the brain, although non-selective effects at these doses cannot be ruled out. What is of interest, it has been revealed that $\mathrm{CB} 2$ receptor antagonist, SR144528, causes biphasic effects on the locomotion of mice, increasing spontaneous locomotor activity in the DBA $/ 2$ mouse at low doses $(1.0-10.0 \mathrm{mg} / \mathrm{kg})$ and decreasing this activity at high doses $(20.0 \mathrm{mg} / \mathrm{kg})$ (Onaivi et al. 2008). Although, Sain et al. (2009) as well as Whiteside et al. (2005) revealed that genetic deletion of the $\mathrm{CB} 2$ receptor has not been connected with any change in motor effects. On the other hand, increasing doses of the CB2 receptor agonist, JWH015, decreased locomotor activity and stereotyped behavior what was depended on the gender of animals (Onaivi et al. 2006). Similarly, typical hypolocomotion was observed after administration of an alternative CB2 receptor agonist GW 405833 (Valenzano et al. 2005) but the injection of the selective CB2 receptor agonists HU 308 and AM 1214, at doses provoking significant antinociceptive effects, did not affect locomotor activity (Hanus et al. 1999; Malan et al. 2001).

Additionally, Xi et al. (2011) have revealed that intranasal or intra-accumbens local administration of CB2 receptor agonist, JWH 133, dose-dependently inhibits cocaine-enhanced locomotion in wild-type (WT) and CB1 receptor-knockout (CB1-/-), but not CB2-/- mice. This inhibition is mimicked by GW 405833, another CB2 receptor agonist with a different chemical structure, and is blocked by AM 630, a selective CB2 receptor antagonist. Intra-accumbens administration of JWH 133 alone dose-dependently decreases, while intraaccumbens AM 630 elevates locomotion in WT and CB1-/mice, but not in $\mathrm{CB} 2-/-$ mice.

Our results indicating that $\mathrm{CB} 2$ receptor ligands did not affect locomotor activity in the dose used $(2.0 \mathrm{mg} / \mathrm{kg})$ are consistent also with other literature data (Ishiguro et al. 2010; Kim and Li 2015; Khella et al. 2014; Onaivi 2009; Ortega-Alvaro et al. 2011). The data indicating the role of CB2 receptor agonist in the MK-801-induced disruptions of PPI in mice seem to be interesting (Khella et al. 2014). In this cited experiment, JWH 015, a CB2 receptor agonist had no significant effect on prepulse inhibition (PPI) alone but reversed disruptions in PPI induced by MK-801. This effect was attenuated by the injection of AM 630, but not by AM 251, CB1 receptor antagonist, suggesting an involvement of CB2 receptors in these effects. Additionally, JWH 203, the mixed $\mathrm{CB} 1 / \mathrm{CB} 2$ receptor agonist only partially reduced MK-801-induced PPI disruptions but neither AM 630 nor
AM 251 had any significant effect alone or on MK-801induced disruptions in PPI (Khella et al. 2014). In turn, Ishiguro et al. (2010) have confirmed that AM 630 exacerbated MK-801- or methamphetamine-induced disturbance of PPI and hyperactivity in C57BL/6JJmsSlc mice. Thus, we can suspect that the inhibition of the activity of CB2 receptor by $\mathrm{AM} 630$ at the dose of $2.0 \mathrm{mg} / \mathrm{kg}$ is not able to contribute to the emergence of symptoms of schizophrenia. However, the inhibition of the function of receptor CB2 in combination with other risk factors (e.g., the impairment of glutamatergic transmission by the use of NMDA receptor antagonist-MK-801) may provoke or potentiate the symptoms of schizophrenia, perhaps in the people predisposed to schizophrenia. Perhaps, the possible explanation of our results is connected with the fact that pharmacological ligands targeting CB2 receptor (JWH 133 and AM 630) in the normal conditions (without injection of MK-801) and in the highest dose used $(2.0 \mathrm{mg} / \mathrm{kg})$ had no influence on the locomotor activity in mice. But in the presence of some risk factor of schizophrenia in animals (e.g., administration of MK-801), CB2 expression in the brain is changed and CB2 receptor ligands exhibit potent antipsychotic (anti-hyperactivity) effects. Naturally, we can only support these conclusions and more detailed knowledge of these effects needs further investigations.

The mechanism of action of CB2 receptor ligands in psychosis-like responses in mice is still unclear. Although, a number of studies have investigated the association between cannabis and psychosis, many questions remain unanswered. It has been known that endocannabinoid system, mainly via CB1 receptors, is involved in pathomechanisms of schizophrenia (Barzegar et al. 2015; Kruk-Slomka et al. 2016b; Kucerova et al. 2014; Levin et al. 2012; Roser and Haussleiter 2012), while the CB2 receptors locating outside the CNS are involved in the processes related to the function of the immune system (Fukuda et al. 2014; Pertwee 2010; Wright et al. 2008). However, recent studies have provided evidence that $\mathrm{CB} 2$ receptors may also be arranged outside the cells of the immune system. Literature data suggested that these receptors can also be found in various brain regions of humans and many animal species (Benito et al. 2008; Zhang et al. 2014). The studies on the biochemical and histological level have revealed that the $\mathrm{CB} 2$ receptors are located in the neuronal progenitor cells, neurons, glial chambers, and endothelium. There is also evidence for the expression of CB2 receptors in areas of the brain that are particularly pertinent to the context of schizophrenia, such as regions involved in sensorimotor gating (Onaivi 2009; Racz et al. 2008; Zhang et al. 2014), but the functional significance of this discovery has not been established yet.

Following that, the functional role of central CB2 receptors is not fully elucidated yet. Recent evidence obtained from pharmacological (Ishiguro et al. 2010; Kim and Li 2015; Onaivi 2009; Ortega-Alvaro et al. 2011) and genetic studies 
(Ortega-Alvaro et al. 2011) suggest that centrally expressed CB2 receptors are involved in many processes of neuropsychiatric disorders, such as behavior characteristic of schizophrenia, impulsive behavior, locomotor activity, stereotyped behaviors, anxiety-, pain-, and memory-related processes (Khella et al. 2014; Kim and Li 2015; Kruk-Slomka et al. 2016a). Moreover, literature data (Kruk-Slomka et al. 2015; Onaivi 2009) revealed the possible involvement of CB2 receptors in depression, which may be of importance in many psychiatric disorders connecting with emotional imbalance, including schizophrenia. What is more, the literature data indicated that the deletion of the gene encoding CB2 receptors may lead to neurochemical changes which can be a consequence of a behavioral disorder mentioned above (Ishiguro et al. 2010; Ortega-Alvaro et al. 2011).

We confirmed in results presented in this paper that both stimulation and blockade of $\mathrm{CB} 2$ receptors is able to modulate locomotor activity of mice that correlates with the neuropsychiatric effects. It has been known that the neuropsychiatric effects of endocannbinoid system, via CB1 and CB2 receptors, are associated with the modulation of different neurotransmitter systems, such as dopaminergic system, glutamatergic system, or GABA-related system (Broome et al. 2005; Carlsson et al. 2004). A variety of pre-clinical and clinical studies have indicated that mainly $\mathrm{CB} 1$ receptors participate in many central pathways connected with psychosis-like state through influence on the glutamatergic transmission (Barzegar et al. 2015; Kruk-Slomka et al. 2016b). However, in the case of CB2 receptors, many literature data suggested an important role of $\mathrm{CB} 2$ receptors, locating in the specific brain areas, mainly on the dopaminergic neurons in the ventral tegmental area (VTA). Electrophysiological studies have demonstrated that CB2 receptor activation by JWH 133 or other CB2 receptor agonists leads to inhibition of dopaminergic neuron activation in the VTA. Therefore, these CB receptors play an important role in the modulation of dopaminergic system and are involved in the behaviors connecting with dopaminergic system-related disorders, such as schizophrenia, anxiety, depression, and Parkinson disease (Zhang et al. 2014). Additionally, the endocannabinoid system via CB2 receptors can be associated with schizophrenia-like response, due to the fact that this type of receptors is responsible for the increase of amount of annandamide, the main endocannabinoid occurring in the brain. The clinical studies confirmed that the clinical remission of schizophrenia may be connected with the significant decrease in the level of anandamide and messenger ribonucleic acid (mRNA) encoding CB2 receptors (Ishiguro et al. 2010; Vigano et al. 2008). However, there are significant species differences in $\mathrm{CB} 2$ receptor mRNA splicing and expression, protein sequences, and $\mathrm{CB} 2$ receptor ligand-related in mice and rats (Zhang et al. 2015) indicating that the cellular mechanisms underlying these actions are still unclear; therefore, the function of cannabinoid $\mathrm{CB} 2$ receptors in the brain have been subject to debate. Following that, the influence of CB2 agonists and antagonists on hyperlocomotion of mice is controversial and inconsistent, for this reason need further investigation.

\section{Conclusion}

The results presented in this paper, as well as the cited literature data, allow evaluating the possible relationship between endocannbinoid system and positive symptoms of schizophrenia, focusing on the CB2 receptors. It can also be assumed that modulation of the $\mathrm{CB} 2$ receptor function in combination with other risk factors (e.g., disturbances in the glutamatergic transmission) may lead to the onset or intensification of the symptoms of schizophrenia. However, further behavioral studies would be required to conclusively establish the role of $\mathrm{CB} 2$ receptors in schizophrenia and would be essential in understanding and developing the pharmacological profile of novel antipsychotics in the future.

\section{Compliance with Ethical Standards}

Conflict of Interest The authors declare that they have no conflict of interest.

Ethical Approval All applicable international, national, and/or institutional guidelines for the care and use of animals were followed. All experiments were conducted according to the National Institute of Health Guidelines for the Care and Use of Laboratory Animals and to the European Community Council Directive for the Care and Use of laboratory animals of 22 September 2010 (2010/63/EU), and approved by the local ethics committee. All procedures performed in studies involving animals were in accordance with the ethical standards of the institution or practice at which the studies were conducted.

Informed Consent Informed consent was obtained from all individual participants included in the study. Additional informed consent was obtained from all individual participants for whom identifying information is included in this article.

Open Access This article is distributed under the terms of the Creative Commons Attribution 4.0 International License (http:// creativecommons.org/licenses/by/4.0/), which permits unrestricted use, distribution, and reproduction in any medium, provided you give appropriate credit to the original author(s) and the source, provide a link to the Creative Commons license, and indicate if changes were made.

\section{References}

Almeida V, Peres FF, Levin R, Suiama MA, Calzavara MB, Zuardi AW, Hallak JE, Crippa JA, Abílio VC (2014) Effects of cannabinoid and vanilloid drugs on positive and negative-like symptoms on an animal model of schizophrenia: the SHR strain. Schizophr Res 153(13):150-159 
Arseneault L, Cannon M, Witton J, Murray RM (2004) Causal association between cannabis and psychosis: examination of the evidence. Br J Psychiatry 184:110-117

Barzegar S, Komaki A, Shahidi S, Sarihi A, Mirazi N, Salehi I (2015) Effects of cannabinoid and glutamate receptor antagonists and their interactions on learning and memory in male rats. Pharmacol Biochem Behav 131:87-90

Benito C, Tolón RM, Pazos MR, Núñez E, Castillo AI, Romero J (2008) Cannabinoid CB2 receptors in human brain inflammation. Br J Pharmacol 153(2):277-285

Bolognini D, Cascio MG, Parolaro D, Pertwee RG (2012) AM630 behaves as a protean ligand at the human cannabinoid $\mathrm{CB} 2$ receptor. Br J Pharmacol 165(8):2561-2274

Broome MR, Woolley JB, Tabraham P, Johns LC, Bramon E, Murray GK, Pariante C, McGuire PK, Murray RM (2005) What causes the onset of psychosis? Schizophr Res 79(1):23-34

Bubenikova-Valesova V, Svoboda J, Horacek J, Sumiyoshi T (2010) Effect of tandospirone, a serotonin-1A receptor partial agonist, on information processing and locomotion in dizocilpine-treated rats. Psychopharmacology 212(2):267-276

Carlsson ML, Carlsson A, Nilsson M (2004) Schizophrenia: from dopamine to glutamate and back. Curr Med Chem 11(3):267-277

Ferrari F, Ottani A, Vivoli R, Giuliani D (1999) Learning impairment produced in rats by the cannabinoid agonist HU 210 in a watermaze task. Pharmacol Biochem Behav 64(3):555-561

Fukuda S, Kohsaka H, Takayasu A, Yokoyama W, Miyabe C, Miyabe Y, Harigai M, Miyasaka N, Nanki T (2014) Cannabinoid receptor 2 as a potential therapeutic target in rheumatoid arthritis. BMC Musculoskelet Disord 15:275

Grotenhermen F (2004) Pharmacology of cannabinoids. Neuro Endocrinol Lett 25(1-2):14-23

Hanus L, Breuer A, Tchilibon S, Shiloah S, Goldenberg D, Horowitz M, Pertwee RG, Ross RA, Mechoulam R, Fride E (1999) HU-308: a specific agonist for $\mathrm{CB}(2)$, a peripheral cannabinoid receptor. Proc Natl Acad Sci U S A 96:14228-14233

Ishiguro H, Horiuchi Y, Ishikawa M, Koga M, Imai K, Suzuki Y, Morikawa M, Inada T, Watanabe Y, Takahashi M, Someya T, Ujike H, Iwata N, Ozaki N, Onaivi ES, Kunugi H, Sasaki T, Itokawa M, Arai M, Niizato K, Iritani S, Naka I, Ohashi J, Kakita A, Takahashi H, Nawa H, Arinami T (2010) Brain cannabinoid CB2 receptor in schizophrenia. Biol Psychiatry 67(10):974-982

Khella R, Short JL, Malone DT (2014) CB2 receptor agonism reverses MK-801-induced disruptions of prepulse inhibition in mice. Psychopharmacology 231(16):3071-3387

Kim J, Li Y (2015) Chronic activation of CB2 cannabinoid receptors in the hippocampus increases excitatory synaptic transmission. J Physiol 593(4):871-886

Kovacic P, Somanathan R (2010) Clinical physiology and mechanism of dizocilpine (MK-801): electron transfer, radicals, redox metabolites and bioactivity. Oxidative Med Cell Longev 3(1):13-22

Kruk-Slomka M, Biala G (2016) CB1 receptors in the formation of the different phases of memory-related processes in the inhibitory avoidance test in mice. Behav Brain Res 301:84-95

Kruk-Slomka M, Michalak A, Biala G (2015) Antidepressant-like effects of the cannabinoid receptor ligands in the forced swimming test in mice: mechanism of action and possible interactions with cholinergic system. Behav Brain Res 284:24-36

Kruk-Slomka M, Boguszewska-Czubara A, Slomka T, Budzynska B, Biala G (2016a) Correlations between the memory-related behavior and the level of oxidative stress biomarkers in the mice brain, provoked by an acute administration of $\mathrm{CB}$ receptor ligands. Neural Plast ID 9815092:1-16 doi: 10.1155/2016/9815092

Kruk-Slomka M, Budzynska B, Slomka T, Banaszkiewicz I, Biala G (2016b) The influence of the CB1 receptor ligands on the schizophrenia-like effects in mice induced by MK-801. Neurotox Res:1-19, doi: 10.1007/s12640-016-9662-0
Kucerova J, Tabiova K, Drago F, Micale V (2014) Therapeutic potential of cannabinoids in schizophrenia. Recent Pat CNS Drug Discov $9(1): 13-25$

Large M, Sharma S, Compton MT, Slade T, Nielssen O (2011) Cannabis use and earlier onset of psychosis: a systematic meta-analysis. Arch Gen Psychiatry 68(6):555-561

Levin R, Almeida V, Peres FF, Calzavara MB, da Silva ND, Suiama MA, Niigaki ST, Zuardi AW, Hallak JE, Crippa JA, Abílio VC (2012) Antipsychotic profile of cannabidiol and rimonabant in an animal model of emotional context processing in schizophrenia. Curr Pharm Des 18(32):4960-4965

Lewis DA, Lieberman JA (2000) Catching up on schizophrenia: natural history and neurobiology. Neuron 28(2):325-334

Lichtman AH (2000) SR 141716A enhances spatial memory as assessed in a radial-arm maze task in rats. Eur J Pharmacol 404(1-2):175-179

Liu QR, Pan CH, Hishimoto A, Li CY, Xi ZX, Llorente-Berzal A, Viveros MP, Ishiguro H, Arinami T, Onaivi ES, Uhl GR (2009) Species differences in cannabinoid receptor 2 (CNR2 gene): identification of novel human and rodent CB2 isoforms, differential tissue expression and regulation by cannabinoid receptor ligands. Genes Brain Behav 8(5):519-530

Malan TP Jr, Ibrahim MM, Deng H, Liu Q, Mata HP, Vanderah T, Porreca F, Makriyannis A (2001) CB2 cannabinoid receptor-mediated peripheral antinociception. Pain 93:239-245

Marsicano G, Goodenough S, Monory K, Hermann H, Eder M, Cannich A, Azad SC, Cascio MG, Gutiérrez SO, van der Stelt M, LópezRodriguez ML, Casanova E, Schütz G, Zieglgänsberger W, Di Marzo V, Behl C, Lutz B (2003) CB1 cannabinoid receptors and on-demand defense against excitotoxicity. Science 302(5642):84-88

Mohn AR, Gainetdinov RR, Caron MG, Koller BH (1999) Mice with reduced NMDA receptor expression display behaviors related to schizophrenia. Cell 98(4):427-436

Moore C, Rana S, Coulter C (2007) Simultaneous identification of 2carboxy-tetrahydrocannabinol, tetrahydrocannabinol, cannabinol and cannabidiol in oral fluid. J Chromatogr B Analyt Technol Biomed Life Sci 852(1-2):459-464

Nestler EJ, Hyman SE (2010) Animal models of neuropsychiatric disorders. Nat Neurosci 13(10):1161-1169

Onaivi ES (2009) Cannabinoid receptors in brain: pharmacogenetics, neuropharmacology, neurotoxicology, and potential therapeutic applications. Int Rev Neurobiol 88:335-369

Onaivi ES, Ishiguro H, Gong JP, Patel S, Perchuk A, Meozzi PA, Myers L, Mora Z, Tagliaferro P, Gardner E, Brusco A, Akinshola BE, Liu QR, Hope B, Iwasaki S, Arinami T, Teasenfitz L, Uhl GR (2006) Discovery of the presence and functional expression of cannabinoid CB2 receptors in brain. Ann N Y Acad Sci 1074:514-536

Onaivi ES, Ishiguro H, Gong JP, Patel S, Meozzi PA, Myers L, Perchuk A, Mora Z, Tagliaferro PA, Gardner E, Brusco A, Akinshola BE, Hope B, Lujilde J, Inada T, Iwasaki S, Macharia D, Teasenfitz L, Arinami T, Uhl GR (2008) Brain neuronal CB2 cannabinoid receptors in drug abuse and depression: from mice to human subjects. PLoS One 3:e1640

Ortega-Alvaro A, Aracil-Fernández A, García-Gutiérrez MS, Navarrete F, Manzanares J (2011) Deletion of CB2 cannabinoid receptor induces schizophrenia-related behaviors in mice. Neuropsychopharmacology 36(7):1489-1504

Pamplona FA, Takahashi RN (2006) WIN 55212-2 impairs contextual fear conditioning through the activation of $\mathrm{CB} 1$ cannabinoid receptors. Neurosci Lett 397(1-2):88-92

Pertwee RG (2010) Receptors and channels targeted by synthetic cannabinoid receptor agonists and antagonists. Curr Med Chem 17(14): $1360-1381$

Racz I, Nadal X, Alferink J, Baños JE, Rehnelt J, Martín M, Pintado B, Gutierrez-Adan A, Sanguino E, Manzanares J, Zimmer A, Maldonado R (2008) Crucial role of $\mathrm{CB}(2)$ cannabinoid receptor 
in the regulation of central immune responses during neuropathic pain. J Neurosci 28(46):12125-121235

Radhakrishnan R, Wilkinson ST, D'Souza DC (2014) Gone to pot-a review of the association between cannabis and psychosis. Front Psychiatry 5:54

Rapp C, Bugra H, Riecher-Rössler A, Tamagni C, Borgwardt S (2012) Effects of cannabis use on human brain structure in psychosis: a systematic review combining in vivo structural neuroimaging and post mortem studies. Curr Pharm Des 18(32):5070-5080

Roser P, Haussleiter IS (2012) Antipsychotic-like effects of cannabidiol and rimonabant: systematic review of animal and human studies. Curr Pharm Des 18(32):5141-5155

Ross RA, Brockie HC, Stevenson LA, Murphy VL, Templeton F, Makriyannis A, Pertwee RG (1999) Agonist-inverse agonist characterization at CB1 and CB2 cannabinoid receptors of L759633, L759656, and AM630. Br J Pharmacol 126(3):665-672

Sain NM, Liang A, Kane SA, Urban MO (2009) Antinociceptive effects of the non-selective cannabinoid receptor agonist CP 55,940 are absent in CB1(-/-) and not CB2(-/-) mice in models of acute and persistent pain. Neuropharmacology 57:235-241

Svízenská I, Dubový P, Sulcová A (2008) Cannabinoid receptors 1 and 2 (CB1 and $\mathrm{CB} 2$ ), their distribution, ligands and functional involvement in nervous system structures - a short review. Pharmacol Biochem Behav 90(4):501-511

Takahashi RN, Pamplona FA, Fernandes MS (2005) The cannabinoid antagonist SR141716A facilitates memory acquisition and consolidation in the mouse elevated T-maze. Neurosci Lett 380(3):270-275

Terranova JP, Storme JJ, Lafon N, Pério A, Rinaldi-Carmona M, Le Fur G, Soubrié P (1996) Improvement of memory in rodents by the selective CB1 cannabinoid receptor antagonist, SR 141716. Psychopharmacology 126(2):165-172

Valenzano KJ, Tafesse L, Lee G, Harrison JE, Boulet JM, Gottshall SL, Mark L, Pearson MS, Miller W, Shan S, Rabadi L, Rotshteyn Y, Chaffer SM, Turchin PI, Elsemore DA, Toth M, Koetzner L,
Whiteside GT (2005) Pharmacological and pharmacokinetic characterization of the cannabinoid receptor 2 agonist, GW405833, utilizing rodent models of acute and chronic pain, anxiety, ataxia and catalepsy. Neuropharmacology 48:658-672

Vigano D, Guidali C, Petrosino S, Realini N, Rubino T, Di Marzo V, Parolaro D (2008) Involvement of the endocannabinoid system in phencyclidine-induced cognitive deficits modelling schizophrenia. Int J Neuropsychopharmacol 12(5):599-614

Whiteside GT, Gottshall SL, Boulet JM, Chaffer SM, Harrison JE, Pearson MS, Turchin PI, Mark L, Garrison AE, Valenzano KJ (2005) A role for cannabinoid receptors, but not endogenous opioids, in the antinociceptive activity of the CB2-selective agonist, GW405833. Eur J Pharmacol 528:65-72

Wright KL, Duncan M, Sharkey KA (2008) Cannabinoid CB2 receptors in the gastrointestinal tract: a regulatory system in states of inflammation. Br J Pharmacol 153(2):263-270

Xi Z-X, Peng X-Q, Li X, Song R, Zhang H, Liu Q-R, Yang H-J, Bi G-H, Li J, Gardner EL (2011) Brain cannabinoid CB2 receptors modulate cocaine's actions in mice. Nat Neurosci 14(9):1160-1166

Zhang HY, Gao M, Liu QR, Bi GH, Li X, Yang HJ, Gardner EL, Wu J, Xi ZX (2014) Cannabinoid CB2 receptors modulate midbrain dopamine neuronal activity and dopamine-related behavior in mice. Proc Natl AcadSci U S A 111(46):5007-5015

Zhang HY, Bi GH, Li X, Li J, Qu H, Zhang SJ, Li CY, Onaivi ES, Gardner EL, Xi ZX, Liu QR (2015) Species differences in cannabinoid receptor 2 and receptor responses to cocaine selfadministration in mice and rats. Neuropsychopharmacology 40(4):1037-1051

Zhou FC, Xiang YT, Wang CY, Dickerson F, Au RW, Zhou JJ, Zhou Y, Shum DH, Chiu HF, Man D, Lee EH, Yu X, Chan RC, Ungvari GS (2012) Characteristics and clinical correlates of prospective memory performance in first-episode schizophrenia. Schizophr Res 135(13):34-39 